\title{
Empowerment of Urban Refugee Youths in Nairobi County, Kenya: A Socio-Economic Perspective
}

\author{
Duncan Mutisya Kamau and Mary Nyawira Mwenda
}

\section{ABSTRACT}

The ever-increasing rate of urbanization has led to a surge in the number of refugees and asylum seekers in the urban areas in the twenty first century. Much is not known whether these individuals can become self-empowered in coming years and avoid overreliance on humanitarian aid initiated through different projects. This study sought to establish the influence of socio-economic factors on empowerment of urban refugee youths in Nairobi County, Kenya. The objectives of the study were to examine the influence of human capital development and financial capital development factors on empowerment of urban refugee youths. The study was grounded on the Empowerment and Assimilation theories. The study adopted descriptive survey research design. The study's target population was 2972 urban refugee youths aged between 1826 years who were registered by UNHCR and RAS and lived in Nairobi County. The study's sample size was 297 . The study adopted proportionate stratified sampling techniques. Quantitative data was collected by use of research questionnaires and the data was coded by Statistical Packages for Social Sciences (SPSS). The statistical tools of analysis used for descriptive data were arithmetic mean and standard deviation, with the variables attaining a composite mean ranging between 4.03 and 3.72 and standard deviation ranging between 0.966 and 1.127 . The statistical tools of analysis used for inferential statistics was Pearson Correlation Coefficient, with the variables attaining a strong positive correlation ranging between 0.896 and 0.868 . The study concluded that human capital development and financial capital development factors influence empowerment of urban refugee youths in Nairobi County, Kenya. The study recommended support organizations to engage more professionals to equip urban refugee youths with more relevant and numerous skills that will develop their human capital as well as increase funds that support urban refugee youths in starting their businesses in order for them to achieve financial capital development.

Keywords: Empowerment, Human Capital, Development, Financial Capital, Urban Refugee Youths.
Submitted : January 21, 2021

Published : February 16, 2021

ISSN: 2507-1076

DOI: $10.24018 /$ ejbmr.2021.6.1.707

Duncan Mutisya Kamau*

University of Nairobi, Kenya.

(e-mail: mutisyaduncan ${ }^{\circledR}$ yahoo.com) Mary Nyawira Mwenda

School of Open and Distance Learning

University of Nairobi, Kenya.

(e-mail: mmwenda@uonbi.ac.ke)

*Corresponding Author

\section{INTRODUCTION}

Humanitarian organizations, governments, well-wishers together with UNHCR have been working together to improve the general wellbeing of the refugees, offer required protection and access to refugee rights but the funding levels have in most cases been insufficient to reach the enormity of their needs across the globe [1]. Refugees or asylum seekers population across the world in 2019 was 72.5 million with the largest percentage of them ( 5 million) from Syria who have fled the civil war [2]. Majority of these refugees find their way in European nations such as Germany, seeking asylum and among them are almost 26 million refugees who are youths of age between 18-26 years [3]. When these refugees are not given an opportunity for becoming economically empowered, then sustainable solutions are never achieved [4]. When the refugees lack opportunities in the camps that can make them achieve some form of socioeconomic empowerment, they get themselves in urban areas through corrupt or illegal means with hope of getting employment and fulfilling their needs [5]. There has been a huge migration of refugees in Kenya with a majority running away from political conflict and other humanitarian crisis in the adjacent and neighboring countries. The relative stability in Kenya, its booming economy in the region and porous borders with the neighbors have been the major contributors to Kenya being a host to many refugees from the region since 1960s [3]. In Nairobi, the urban fabric has absorbed large number of the refugees. They are also very mobile and are dispersed across the city. The data from [6] revealed that the number of refugees who call the capital their home and are officially registered was 32,000. As we speak now, the number has risen to 73,829 though the real figure could be more than 120,000. Despite of Kenya being a home to very many individuals seeking protections in the East African region such as refugees and asylum seekers, the nation has not developed clear policies and guidelines on how to deal with the refugees unlike its neighbors such as Ethiopia, Uganda and Tanzania [6]. Apart from UNHCR, several nongovernmental organizations work towards making the life of refugees in Nairobi better. Among them are Refugee Consortium of Kenya (RCK) and Kituo cha Sheria for legal matters, GTZ for health care, Hebrew Immigrants Aid 
Society (HIAS), FARAJA Trust, Tushirikiane Afrika (TUSA), Windle International Kenya (WIK), Jesuit Refugee Services (JRS) among others [11]. Local partnership with other humanitarian agencies play a very important role in UNHCR's protection and outreach strategy in Nairobi [7].

The local government especially the county government of Nairobi has been able to provide a good working relation with humanitarian bodies. This has enabled the UNHCR to expand its involvement with the urban refugee population. The local authorities also provide necessary information in identifying the persons that are refugees but not officially registered as refugees for the fear of one reason or another [8]. Several factors make the refugees to avoid or leave the camps that are supposed to host them such as insecurity, refugees urban background, very few opportunities in camps, inadequate medical and educational services in camps. The refugees also migrate to urban areas hoping to get opportunities to migrate to other countries [9]. The urban refugee youths live in a growing city of around 4.5 million people in Nairobi. Almost $40 \%$ of this citizen population is unemployed; around $50 \%$ live below poverty line with around $60 \%$ of this population dwelling in slums.

These young refugee men and women find themselves in these harsh conditions when they move into the city [10]. The large populations of unemployed youth can be a threat to security of a country. However, if proper education and training, health services and employment are availed to them, these young men and women can be a very good asset for all societies by being able to rejuvenate the economy of a country and its institutions [7].

\section{A. Statement of the Problem}

Although UNHCR advocates for the urban refugee rights, the refugees who are youth in the urban setting still find themselves in very difficult settings due to high youth unemployment rates. They have to cope with urban setting challenges that present the barriers that are very unique to their economic success and empowerment. Despite several projects being initiated by the state and non-state actors to support refugee youths to become empowered and gain access to refugee rights, very large gaps exist in ensuring that they are able to sustain their lives without over-reliance on the donors and other agencies especially in their adulthood [11]. By not addressing refugee youth empowerment issues or shifting from the traditional approach of seeing refugee youths as vulnerable groups to paradigm approach (recognizing refugee youths capacities and empowering them) then no sustainable solution is being achieved [2]. Several researchers identified several factors; refugee education, financial literacy, capital, market linkages and forming solidarity [12] and training on entrepreneurship [13] as having a positive influence on empowerment. However, no study has been done regarding how socioeconomic factors contribute to empowerment of urban refugee youths. This study intended to fill a gap by answering to the question; what is the influence of socioeconomic factors on empowerment of urban refugee youths in Nairobi County, Kenya.

\section{B. Objectives of the Study}

The study's objectives were:

1. To examine the influence of human capital development on empowerment of urban refugee youths in Nairobi County, Kenya.

2. To assess the influence of financial capital development on empowerment of urban refugee youths in Nairobi County, Kenya.

\section{LITERATURE REVIEW}

[14] advocates for refugee organizations and networks support as a very important strategy in building local capacity and promoting empowerment of urban refugees. International actors together with local actors through various financial, moral and technical means via initiated projects and programs may play a vital and key role in making sure that there is socio-economic empowerments of the refugees at different group levels such as women, men, girls, youths and other special groups. This can greatly be enhanced by inter-agency coordination around the particular groups. Empowerment ensures that a particular group is capable of participating in UNHCR planning, implementation and evaluation by providing awareness.

[11] argues that the programmes and projects aimed at empowerment of refugees should come up with connections that are explicit between theories, policies, best practices and research from empowerment point of view. In order to ensure there is high percent of empowerment among the refugee groups, programme planners, policy makers and researcher have to ensure that proper attention is given to particular models of empowerment and find out at what settings and which populations greater results are found and why. By determining appropriate measures of developing human capital and financial capital, it means the refugees are able to meet some needs that may have not or are unable to be met by state and non- state support groups [11]. Human capital and financial capital development cannot therefore be compromised when striving to ensure various groups are empowered [6].

[15] in their study on fishing communities in Indonesia argue that the effect on human capital on social empowerment can be very great since they are knowledge increasing hence leading to improved fishing methods and also fish processing. Human capital can greatly be improved through education and training of individuals. When there is improvement in knowledge, the communities could more likely face indirect improvements in their social welfare and better community, which can also imply that they have acquired empowerment through the aspect of human capital. Most communities or members of those communities can become more innovative and more adaptive in running their daily lives if proper knowledge and training is imparted upon them, which may further enable them to move out of poverty.

[16] also points out that with welfare of communities improving through gender based social empowerments set within human capital, may be the main determinant in accelerating the communities self-reliance both socially and economically hence having a huge impact on the communities overall socio-economic empowerment. [17] in 
their study argue that the interaction between human capital, empowerment and performance may be very insignificant when the non-financial measures are put into consideration regardless of a statistically significant model, when financial measures are being considered, the model may be statistically insignificant. Although the later further argue that human capital development may lead to employee empowerment, but the results on performance may be regarded to beat a very minimal extent. Skills and knowledge possessed by individuals greatly depicts their empowerment since it determines the quality of the decisions that they have to make. When human capital is built, the highly skilled individuals may end up being empowered so that they may be able to come up with decisions that they are able to handle well. According to [18] building human capital development through training on skills may significantly increase the empowerment on individuals.

[19] in their study on women economic empowerment argue that human capital development through education, training and skill development may have great influence on breaking poverty cycles at the same time improving the labor market outcomes. Educating young populations especially girls in primary schools means increasing their economic outcomes in future while adult training on different skills may help families to be economically empowered at different capacities and be able to meet the needs that may not be met by state and non-state agencies.

[20] argue that improving the youth skills may lead to greater human capital development which may have a positive influence on economic development. Although the skills must be matched with society or the company's needs. This implies that the programs in training must be aligned with the current needs and also project the future need of the society if possible.

[21] in their study demonstrate that financial attitude, financial literacy, and financial wellbeing is of more importance when considering the economic empowerment of women or any other vulnerable groups. A common generalization is that level of education and financial knowledge among these groups plays very significant role in ensuring that they come up with right financial decisions hence has a direct contribution towards their economic empowerment. Financial attitude may also have a direct contribution towards empowerment since it is linked directly with financial knowledge. The study further found that economic empowerment may also result from financial wellbeing of the individuals.

[22] all processes and forms of financial incorporation may have the potential to produce a positive experience on the social empowerment. Similarly, [23] also argue that financial capital development may have a positive impact on political empowerment in the case of women. This implies that the power to bargain in the society increases, meaning, there is increased freedom for political affiliation, greater negotiations, freedom to engage in political choices, proper family decision making and hence higher empowerment.

Although [24] note that there may be a positive linkage between financial capital development and the several dimension of empowerment, the long term sustainability of these dimensions depend on the involvement of the target group in the economic activity generation through supportive mechanisms and also come up with systems that are superior and also easier interactions on platforms among the stakeholders involved.

Focusing on ways of promoting financial services and products access may help in transforming lives of targeted people and hence their empowerment, although access alone may not show positive results. Financial access may play a very important role in improving on financial capital development hence ensuring equitability. Digital financial services can help in promoting economic empowerment and foster broader positive effects [21].

\section{A. Theoretical Framework}

The research study was anchored on the Empowerment and Assimilation theories.

\section{The Empowerment Theory}

This research study borrowed from empowerment theory model in order to link between influence of socioeconomic factors on the empowerment of the urban refugee youths. Empowerment can be considered as a value orientation for working in the society and also as a theoretical model for helping to understand the consequences and process of effort to impact control and affect the decisions which have an effect in personal life, functioning of organization and also the community life quality [25].

Empowerment theory is very useful to help in distinguishing between the values that matter on empowerment approach to social change. Empowerment theory gives principles and framework that help to organize knowledge and advance the concept beyond political manipulation and passing fad. According to this theory, different approaches of interventions are suggested in order to create social change. Attention towards health, competence, natural helping systems and adaption is diverted. According to this perspective, unequal distribution of resources may very likely result to social problems. Serving individuals with mutual help or working towards their rights instead of fulfilling their needs can really put a positive impact in their empowerment process [25].

\section{Assimilation Theory}

Assimilation theory segmented by Portes and Zhou in 1993 portrays the three aspects of which refugees adapt to a new environment and society. The straight line theory of upward mobility notes that vast majority of immigrants assimilate into the Caucassian who may be the majority middle class, ethnic solidarity of upward mobility which is in successful ethnic entity that establishes itself through social and government policies and lastly an unsuccessful pattern which consists of a downward spiral which results in assimilation into poverty, more often in an underclass inner city. Due to the refugees racial and ethnic origins, the refugees find it not easy to blend compared to their predecessors. By not accessing adequate economic and social support, the children of refugees and the youth refugees end up being more vulnerable to this unsuccessful acculturation pattern. At times, parents and children my acculturate at a similar pace and also in similar ways leading to what is known as consonant acculturation. They further suggest that if this last type of acculturation occur, it may end up leading to parent and children conflict and also communication 
breakdown between the generations. Since the ability of parent to guide and give support to their children is diminished, dissonant acculturation is seen as the main risk factor for downward assimilation among the second generation.

\section{B. Conceptual Framework for the Study}

A conceptual frame work is a hypothetical model that explains how the independent and dependent variables are related by identifying the model which is under the study. A variable is defined as a concept that can utilize both qualitative data aspects and those aspects of quantitative data.

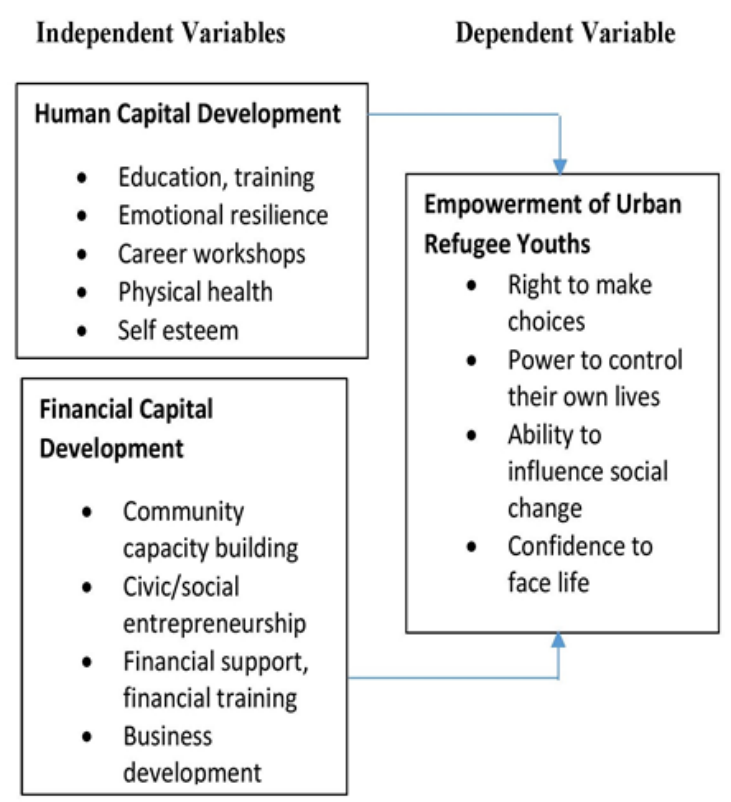

Fig. 1. Conceptual framework.

\section{RESEARCH Methodology}

Descriptive survey design is that which was basically used in this study. Descriptive Survey Design according to [26], gives accounts of the current events as they are whereas explanatory research design generates operational definitions especially for problems that have not been well researched. [27] also highlights that descriptive survey design is very important to a research study since it considers all the aspects of an event while putting in use a unit study and investigation.

This study targeted a population that constituted of urban refugee youths aged between 18 years and 26 years, totaling to 2972 respondents. The sample size indicative of the study population was 297 , derived from [26]. The study adopted proportionate stratified sampling techniques. Quantitative data was collected by use of research questionnaires. The collected data was analyzed by both descriptive analysis and inferential analysis so as to determine the extent to which the variables were related.

\section{FINDINGS AND Discussions}

Quantitative data was analyzed using arithmetic mean, standard deviation, and Pearson correlations.

\section{A. General Personal Information of the Respondents}

Out of a total of two hundred and ninety seven questionnaires that were issued out to the respondents only one hundred and fifty one were returned duly filled. This accounts for $50.84 \%$ of the targeted sample. Statistically, [27] recommend a feedback rate of at least 30 percent to be sufficient for conducting analysis. The response rate of 151 dully filled questionnaires attained by this study was therefore considered to be sufficient for an in-depth analysis.

\section{B. Distribution of Respondents by Gender}

The research sought to determine the respondents' place of employment. The results are as indicated in Table I.

\begin{tabular}{cccc} 
& \multicolumn{3}{c}{ TABLE I: RESPONDENTS' ORGANIZATION } \\
\hline Gender & Frequency & Percent & $\begin{array}{c}\text { Cumulative } \\
\text { Percent }\end{array}$ \\
\hline Male & 103 & $68.2 \%$ & $68.2 \%$ \\
Female & 48 & $31.8 \%$ & $100 \%$ \\
\hline
\end{tabular}

This shows that out of 151 respondents who took part in the study, 103(68.2 percent) were male compared to their female counterparts who were 48 (31.8 percent) which is almost a half of their male counterparts. The gender distribution was therefore considered appropriate for the study since the perspectives from both genders on influence of socioeconomic factors on empowerment of urban refugee youths were captured in this study.

\section{Respondents' Highest Academic Qualification}

The study sought to determine the highest educational qualifications of the respondents. The results are as set out in Table II.

TABLE II: DISTRIBUTION OF RESPONDENTS BY AGE

\begin{tabular}{ccc}
\hline $\begin{array}{c}\text { Age Bracket } \\
\text { (years) }\end{array}$ & Frequency & Percent \\
\hline Below 19 & 37 & 24.5 \\
$19-23$ & 49 & 32.5 \\
$23-26$ & 65 & 43 \\
Total & 151 & 100 \\
\hline
\end{tabular}

The results in Table II point out that out of 151 respondents who participated in the study, 37(24.5 percent) fell in the age bracket of below 19 years, 49 (32.5 percent) fell between 19-23 age bracket while 65 (43 percent) were of the age between 23-26.

\section{Years Respondents have been living in the Urban Areas}

The study further planned to determine how long the respondents had been living as urban refugees in Nairobi.

The results are as set out in Appendix 1.

From the results, it was ascertained that majority of the respondents $(57 \%)$ had been living as urban refugees for more than ten years while $(21 \%)$ indicated that they have been living as urban refugees for five to ten years and (22\%) indicated that they have been living as urban refugees for less than five years. Most pointed out that they were brought in the city by their parents who are also refugees, some by their friends while others traversed several channels to reach the city seeking for any job opportunity. Most of the urban refugee youths named Somalia, Rwanda, DRC, and Uganda as their countries of origin. 


\section{E. Highest Level of Education of the Respondents}

The study further aimed to establish the highest level of education the respondents possessed so as to establish how well the respondents understood the matters to do with socioeconomic factors affecting the urban refugee youth empowerment.

The findings are presented in Appendix 2.

From the findings in table 2 , a broad proportion of the respondents 61 (40.4 percent) out of the 151 that took part in the study had at least attended a vocational /technical training. 37(24.5 percent) had attained Secondary education, 33 (21.8 percent) had gone up to primary level of education, 15 (9.9 percent) had attained a diploma qualification, and only 5 had a university degree. None of the respondents had a post graduate qualifications. This points out that majority of the respondents had knowledge on what socio-economic empowerment involves and could actively take part in productive socio-economic activities which are geared towards enabling them to get empowered.

\section{F. Analysis of Likert Type of Data}

The study sought to determine the extent to which the respondents agreed with statements relating to human and financial capital development and empowerment of urban refugee youths. The participants were requested to indicate with: Strongly Disagree = 1; Disagree =2; Neutral =3; Agree =4; Strongly Agree =5.

\section{Human Capital Development and Empowerment of Urban Refugee Youths}

The results are indicated in Appendix 3.

The findings showed that out of 151 respondents who took part in the study $42(27.8 \%)$ strongly agreed, 79(52.3\%) agreed, 13(8.6\%) remained neutral, 12(7.9\%) disagreed, $5(3.4 \%)$ strongly disagreed with the line that they were able to access education and training from various support organizations. The line had a mean and standard deviation $(\mathrm{M}=3.96 ; \mathrm{SD}=0.965)$ which showed that education as well as training offered played a key role in ensuring that the urban refugee youths achieved empowerment. Secondly $43(28.5 \%)$ strongly supported the statement that there were frequent career workshops targeting urban refugee youths while 68(45\%) agreed, 23(15.2\%) remained neutral, $11(7.3 \%)$ disagreed and $6(4.0 \%)$ strongly disagreed with the statement. The statement further had a mean and standard deviation $(\mathrm{M}=3.89 ; \mathrm{SD}=1.010)$ indicating that it had a strong influence on the empowerment.

Furthermore, of the respondents who took part in the study, 48(31.8\%) strongly agreed, 63(41.7\%) agreed, $26(17.3 \%)$ remained neutral, $10(6.6 \%)$ disagreed while $4(2.6 \%)$ strongly disagreed that they were able to get support that enabled them to adopt to stressful situations or crisis. The line had a mean and standard deviation $(M=3.98$; $\mathrm{SD}=0.941$ ). On the statement that they had been offered programmes that were geared towards improving their physical health,48(31.8\%) strongly agreed, 67(44.4\%) agreed, 19(12.6\%) were neutral, 9(6.0\%) disagreed while $8(5.2 \%)$ strongly disagreed. The statement had mean and standard deviation ( $\mathrm{M}=3.96 ; \mathrm{SD}=1.026)$, implying that it had a contribution in ensuring that the urban refugee youths got the required empowerment.
Lastly, out of 151 respondents who took part in the study, $50(33.1 \%)$ strongly agreed, 69(45.7\%) agreed, $17(11.3 \%)$ remained neutral, $11(7.3 \%)$ disagreed while $4(2.6 \%)$ strongly disagreed with the line that there were programs geared towards improving their self-esteem. The line further had mean and standard $(\mathrm{M}=4.03 ; \mathrm{SD}=0.966)$ which was higher than the composite mean indicating that it had a major influence in empowering the urban refugee youths. Overall, composite mean and standard deviation were 3.964 and 0.9816 respectively implying that the human capital development was being achieved by various organizations in ensuring that the urban refugee youths become empowered.

\section{Financial Capital Development and Empowerment of Urban Refugee Youths}

The results are as indicated in Appendix 4.

Out of 151 respondents who took part in the study, $35(23.2 \%)$ strongly agreed, 63(41.7\%) agreed, 33(21.9\%) remained neutral, $12(7.9 \%)$ disagreed while $8(5.3 \%)$ strongly disagreed when it came to the statement that there was community capacity building from various organizations that were supporting them. The line further had a mean and standard deviation $(\mathrm{M}=3.70 ; \mathrm{SD}=1.070)$ indicating that it had a positive influence on empowerment of urban refugee youths. On the statement that there were various programs which were geared towards civic/social entrepreneurship, majority of the respondents $36(23.8 \%)$ agreed, $57(37.7 \%)$ strongly agreed, 36(23.8\%) were neutral, $13(8.7 \%)$ disagreed while $9(6 \%)$ strongly disagreed. The line had mean and standard deviation $(\mathrm{M}=3.65 ; \mathrm{SD}=1.115)$.

The urban refugee youths attached to various organizations also agreed that they were also receiving financial support from those organization with $38(25.2 \%)$ strongly agreeing, 68(45\%) agreed, 23(15.2\%) remained neutral, $14(9.3 \%)$ disagreed while $8(5.3 \%)$ strongly disagreed. The statement had mean and standard deviation $(\mathrm{M}=3.75 ; \mathrm{SD}=1.095)$, showing that it had positive influence on empowerment of the urban refugee youths.

Lastly $56(37.1 \%)$ of the respondents strongly agreed, $44(29.1 \%)$ agreed, 24(15.9\%) remained neutral, 18(11.9\%) disagreed while $9(6 \%)$ disagreed that they had at more than one time been subjected to various ideas that were best for business development, with a mean and standard deviation $(M=3.79 ; \mathrm{SD}=1.229)$, implying that it was one of the major determinants of financial capitals influence on empowerment. The overall composite mean and standard deviation ( $M=3.72 ; S D=1.127)$ indicate that various support organizations and agencies had developed various strategies to ensure that there was financial development among the urban refugee youths which is a very critical aspect in seeing to it that they are empowered economically.

\section{G. Inferential Analysis}

Based on the analysis, human capital development has a strong positive correlation (Pearson correlation coefficient $=0.896$ ) influence on empowerment. In addition to that, financial capital development, also has a positive correlation on empowerment (Pearson correlation coefficient=0.868).

The correlation matrix depicts therefore that coming up with different ways of developing the human capital among 
the urban refugee youths as well as developing their financial capital can significantly improve their present and also future socio-economic empowerment. Achieving socio-economic empowerment on this special group will not only solve the current situation but also ensure that their future lives become better and they will grow into individuals that are responsible in the society.

\section{CONCLUSIONS}

The findings that were generated as a result of this study concluded that there existed a positive relationship between human capital development vis-à-vis urban refugee youth empowerment in Nairobi County, Kenya. Human capital development played a very significant role when it came to empowering the urban refugee youths. The urban refugee youth were able to develop their human capital through education and training, participating in frequent career workshops, improving their physical health and their selfesteem. These activities not only improved their human capital but also ensured that they gained socio-economic empowerment.

The study secondly established that training on business skills, ideas, budgeting, financial literacy played a very key role in ensuring that there was financial capital development among the urban refugee youths. Through small source of funding and access to credit that they urban refugee youths were able to access, they were able to run or start up small businesses that could sustain them as they could not rely at all times on funds from the agencies. There was a strong positive relationship between financial capital development and empowerment.

\section{RECOMMENDATIONS}

Support organizations need to engage more professionals to ensure that the urban refugee youths are equipped with more relevant and numerous skills that can ensure that the human capital development is steadily increased. Furthermore human capital development programs are supposed to be geared to ensure that more refugees are involved or engaged.
Though financial capital development had been achieved through financial training and literacy, the target group should be trained by the agencies more on entrepreneurial skills and further more increase the funds that support the urban refugee youths in starting their businesses.

\section{ACKNOWLEDGEMENT}

My gratitude goes to the whole administration and management of the University of Nairobi for their cooperation, support and guidance. I also thank Dr. Mary Mwenda, my supervisor for the intellectual advice and encouragement she has given me. I owe a depth of gratitude to other University of Nairobi Lecturers including Prof. Charles Rambo, Dr. Lillian Omutoko, Dr. Angeline Mulwa and Madam Caren Awilly who gave me assistance and understanding during my course work. My fellow colleagues were instrumental in analyzing the proposal at every stage enabling me to refine the ideas that feature in this proposal. I thank them too. Lastly, I appreciate and want to pay a special thanks to my family for their moral support.

\section{APPENDIX}

APPENDIX 1: YEARS RESPONDENTS HAVE BEEN LIVING IN THE URBAN AREAS

\begin{tabular}{cccc}
\multicolumn{4}{c}{ AREAS } \\
Years & Frequency & Percent & $\begin{array}{c}\text { Cumulative } \\
\text { Percent }\end{array}$ \\
\hline Less than 5 years & 33 & 22 & 22 \\
5-10 years & 86 & 21 & 43 \\
More than 10 & 32 & 57 & 100 \\
years & & & \\
\hline
\end{tabular}

APPENDIX 2: HIGHEST LEVEL OF EDUCATION OF THE RESPONDENTS

\begin{tabular}{ccc}
\hline Level of education & Frequency & Percent \\
\hline KCPE Certificate & 33 & $21.8 \%$ \\
KCSE Certificate & 37 & $24.5 \%$ \\
Vocational Training & 61 & $40.4 \%$ \\
College/Diploma & 15 & $9.9 \%$ \\
Degree & 5 & $3.4 \%$ \\
Post Graduate & 0 & 0 \\
Total & 151 & $100 \%$ \\
\hline
\end{tabular}

\begin{tabular}{|c|c|c|c|c|c|c|c|}
\hline Statement & 5 & 4 & 3 & 2 & 1 & Mean & $\begin{array}{c}\text { Std } \\
\text { Deviation }\end{array}$ \\
\hline Education and training from support organizations & $42(27.8)$ & $79(52.3)$ & $13(8.6)$ & $12(7.9)$ & $5(3.4)$ & 3.96 & .965 \\
\hline Frequent career workshops targeting urban youths & $43(28.5)$ & $68(45.0)$ & $23(15.2)$ & $11(7.3)$ & $6(4.0)$ & 3.89 & 1.010 \\
\hline Support during stressful or crisis times & $48(31.8)$ & $63(41.7)$ & $26(17.3)$ & $10(6.6)$ & $4(2.6)$ & 3.98 & .941 \\
\hline Programs geared towards improving physical health & $48(31.8)$ & $67(44.4)$ & $19(12.6)$ & $9(6.0)$ & $8(5.2)$ & 3.96 & 1.026 \\
\hline Programs geared towards improving self esteem & $50(33.1)$ & $69(45.7)$ & $17(11.3)$ & $11(7.3)$ & $4(2.6)$ & 4.03 & .966 \\
\hline Composite mean and standard deviation & & & & & & 3.964 & .982 \\
\hline
\end{tabular}

APPENDIX 4: FINANCIAL CAPITAL DEVELOPMENT AND EMPOWERMENT OF URBAN REFUGEE YOUTHS

\begin{tabular}{|c|c|c|c|c|c|c|c|}
\hline Statement & 5 & 4 & 3 & 2 & 1 & Mean & $\begin{array}{c}\text { Std. } \\
\text { Deviation }\end{array}$ \\
\hline $\begin{array}{l}\text { Presence of community capacity } \\
\text { building }\end{array}$ & $35(23.2)$ & 63(41.7) & $33(21.9)$ & $12(7.9)$ & $8(5.3)$ & 3.70 & 1.070 \\
\hline $\begin{array}{l}\text { Programs for civic/social } \\
\text { entrepreneurship }\end{array}$ & $36(23.8)$ & $57(37.7)$ & $36(23.8)$ & 13(8.7) & $9(6)$ & 3.65 & 1.115 \\
\hline $\begin{array}{c}\text { Financial support from various } \\
\text { organizations }\end{array}$ & $38(25.2)$ & $68(45)$ & $23(15.2)$ & $14(9.3)$ & $8(5.3)$ & 3.75 & 1.095 \\
\hline $\begin{array}{c}\text { Subjected to ideas that are best for } \\
\text { business development }\end{array}$ & $56(37.1)$ & $44(29.1)$ & 24(15.9) & 18(11.9) & $9(6)$ & 3.79 & 1.229 \\
\hline Composite mean and standard deviation & & & & & & 3.72 & 1.127 \\
\hline
\end{tabular}




\begin{tabular}{|c|c|c|c|c|}
\hline Variables & & $\begin{array}{l}\text { Empowerment of Urban } \\
\text { Refugee Youths. } \\
\end{array}$ & $\begin{array}{c}\text { Human Capital } \\
\text { Development }\end{array}$ & $\begin{array}{c}\text { Financial Capital } \\
\text { Development }\end{array}$ \\
\hline $\begin{array}{c}\text { Empowerment of Urban Refugee } \\
\text { Youths. }\end{array}$ & $\begin{array}{c}\text { Pearson's } \\
\text { (R) } \\
\text { Sig. } \\
\text { (2tailed) }\end{array}$ & 1 & & \\
\hline Human Capital Development & $\begin{array}{c}\text { Pearson's } \\
\text { (R) } \\
\text { Sig. } \\
\text { (2tailed) }\end{array}$ & $\begin{array}{l}.896 \\
.000\end{array}$ & 1 & \\
\hline Financial Capital Development & $\begin{array}{c}\text { Pearson's } \\
\text { (R) } \\
\text { Sig. } \\
\text { (2tailed) }\end{array}$ & .868 & .877 & 1 \\
\hline
\end{tabular}

**. Correlation is significant at the 0.01 level (2-tailed).

\section{REFERENCES}

[1] Campbell, E., Crisp, J., \& Kiragu, E. (2014). Navigating Nairobi: a review of the implementation of UNHCR's urban refugee policy in Kenya's capital city. Geneva: UNHCR.

[2] CFR. (2019, August 1). Retrieved 23 February, 2020, from Empowering Refugees in Times of Crisis: http://www.cfr.org.

[3] UNHCR. (2018). Living on the Edge: A Livelihood Status Report on Urban refugees Living in Nairobi, Kenya. Geneva: UNHCR.

[4] Betts, A. (2017, August 1st ). Empowering Refugees in Times of Crisis. (R. J. Rodriguez, Interviewer).

[5] Carrier, N. (2016). Little Mogadishu: Eastleigh, Nairobi's global Somali hub. London: Hurst\&Co. Publishers.

[6] UNHCR. (2019). Progress in accelerating global actions for a world without poverty and implementation of the System-wide Plan of Action for the Third United Nations Decade for the Eradication of Poverty (2018-2027). Geneva: UNHCR.

[7] Carrier, N. (2016). Little Mogadishu: Eastleigh, Nairobi's global Somali hub. London: Hurst\&Co. Publishers.

[8] Omata, N. (2016). Refugee economies in Kenya: preliminary study in Nairobi and Kakuma camp. Working Paper Series No 120. Refugee studies Centre.

[9] Campbell, E., Crisp, J., \& Kiragu, E. (2011). Navigating Nairobi: a review of the implementation of UNHCR's urban refugee policy in Kenya's capital city. Geneva: UNHCR.

[10] UNHCR. (2016). Global trends : forced displacement in 2016. Geneva: UNHCR

[11] Ayinkamiye, R. (2015). Strategies used by State and non-state actors in empowering refugees in kenya. Nairobi: University of Nairobi:Unpublished MBA Report.

[12] Nyale, N. M. (2018). Youth empowerment and livelihoods: A case of rural youth registered in groups invlved in horticulture production in Trans Nzia County,Kenya. Nairobi: Youth empowerment and livelihoods: A case of rural youth registered in groups invlKenyatta Universityi: Uplished MBA Report.

[13] Koech, B. K. (2014). Contribution of Women Groups in the Economic Empowerment of Rural Women: A Case of Women Groups in Bureti Constituency, Kericho County, Kenya. University of Nairobi: Unpublished MA Report.

[14] UNHCR. (2015). Kenya comprehensive refugee programme 2015. Geneva: UNHCR.

[15] Hartina, B., La, R., Weka, W., Dasmin, S., Nur, R., \& Putu, A. (2018). The effect of human capital, social capital and competency on the empowerment of Bajo ethnic community in the Regency of Muna: A gender Perspective. Agriculture, Forestry and Fisheries, 7 (1), 6-10.

[16] Thompson, M. (2015). Social Capital Innovation and Economic Growth. Documentos the Trabalho Working Paper Series.

[17] Munjiri, M., \& Obonyo, P. (2015). Human capital, employee empowerment and performance of commercial banks and insurance firms in Kenya. International Journal of Arts and Commerce, 4 (6), 163-181.

[18] Yamoah, E. E. (2014). The Link between Human Resource Capacity Building and Job Performance. International Journal of Human Resource Studies, 4 (3), 139-146.

[19] Abigail, H., \& Emma, S. (2016). Women's economic empowerment. London: Oveseas Development Institute.

[20] WTO. (2019). Aid for trade at a glance 2019: Economic Diversification and Empowerment. OECD.

[21] Haque, A., \& Zulfiqar, M. (2016). Women's Economic Empowerment through Financial Literacy, Financial Attitude and Financial Wellbeing. International Journal of Business and Social Science, 7
(3), 78-88.

[22] Chatterjee, S., Dutta, G., \& Upadhyay, P. (2018). Empowering women and stimulating development at bottom of pyramid through microentrepreneurship. Management Decision, 56 (1), 160-174.

[23] Bhattacharyya, R. (2019). Microfinance: A tool for empowering women in India. In R. C. Das (Ed.), Handbook of research on microfinancial impacts on women empowerment, poverty, and inequality. Hershey, PA: IGI Global.

[24] Shivangi, B., \& Seema, S. (2019). Empowering Women Through Financial Inclusion: A Study of Urban Slum. The Journal for Decision Makers, 44 (4), 182-197.

[25] Zimmerman, M. (1998). Empowerment Theory:Psychological, Organizational and Community Levels of Analysis.

[26] Kothari, C. (2005). Research methodology: Methods and Techniques. New Delhi: H.S.

[27] Best, W. (2004). Research in education. Boston: Allyn \& Bacon.

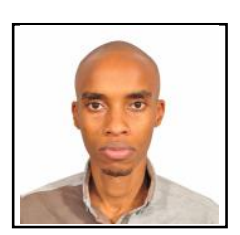

Duncan Mutisya Kamau. Born in Nairobi County, Kenya on $9^{\text {th }}$ April 1991. Attained a Master of Arts Degree in project planning and management from the University of Nairobi, Kenya on $25^{\text {th }}$ September 2020. Attained 60 level 7 credit Postgraduate certificates from Oxford Brookes University in Headington Rd, Oxford, United Kingdom i.e. introduction to humanitarian response on October 2015, advanced humanitarian operations training on January 2016 \& working in the humanitarian context on $23^{\text {rd }}$ June 2016. Attained a Bachelor of Arts Degree in community development from Daystar University Nairobi, Kenya on $28^{\text {th }}$ June 2014.

$\mathrm{He}$ works as a Monitoring and Evaluation Officer for Windle International Kenya (an International Non-governmental organization that assists refugees and needy Kenyans living in Dadaab and Kakuma Refugee camps by providing for them Tertiary education, Secondary education, Primary education, Teacher training and above all Education Scholarships). He has also worked for Lutheran World Federation between March 2017 to March 2018 as a Monitoring and Evaluation Officer in Dadaab Refugee Camp and Save the Children International Kenya between April 2015 - April 2016 as a Humanitarian Trainee in Nairobi and fieldwork placement in Dadaab Refugee Camp. Previous research interests include influence socio-economic factors on empowerment of urban refugee youths in Nairobi County, Kenya. 